\title{
ORAHESIVE AS A PROTECTION FOR THE TEETH DURING GENERAL ANAESTHESIA AND ENDOSCOPY*
}

\author{
William Evers, M.D., Gabor B. Racz, M.B., Jackson Glazer, D.D.S., \\ AND Allen B. Dobkin, M.D.
}

General anaEsthesia and ENDOSCOPY involve instrumentation about the teeth. This may chip, break, or loosen a healthy tooth, avulse a loose one, or damage brittle prosthetic devices. Single-rooted teeth are sometimes levered out, while diseased teeth are often fractured. ${ }^{1}$ Such dental injuries are a common, though rarely justifiable, cause of litigation.

Damage may occur during insertion of an oropharyngeal airway, bite-block or metal suction tip. However, it is most likely to occur during endoscopy (laryngoscopy, bronchoscopy, oesophagoscopy). The upper incisors or, occasionally, the canines are most often injured, especially if improper, though sometimes unavoidable, leverage is exerted on them during endoscopy. ${ }^{2}$ Injury may also occur during emergence from anaesthesia when patients sometimes grind their teeth or vigorously bite on airways.

Although proper care and refined technique often prevent or at least minimize the damage, it behooves even the most skilled anaesthesiologist and endoscopist to take additional precautions to protect the teeth. Various types of mechanical protection for the teeth have been used. They include a few layers of gauze or adhesive tape, ${ }^{3}$ tongue blades, ${ }^{4}$ thin lead sheet, a rubber mould, or a dental plastic stent. 6,6

To be useful and desirable, a protective device should: (1) be quick and easy to apply without discomfort to the patient; (2) be non-irritating to the mucous membranes; (3) mould snugly around the patient's upper teeth, allowing for different oral sizes, angles or abnormal positions; (4) offer the desired protection without encroaching upon the oral cavity; (5) be sterile, disposable, and inexpensive.

The material used in this study was $1 / 16^{\prime \prime}$ Orahesive (E. R. Squibb \& Co.). This is composed of gelatin, pectin, sodium carboxy-methyl-cellulose, and polyisobutylene. It has a great affinity for water, is water-soluble, and will adhere firmly to moist surfaces. Presentation is in individually wrapped wafers in three thicknesses. One surface is backed with polyethylene film and the other with removable release paper. The wafers may be cut to any desired size or shape. The principal use of the material in dentistry is to prevent bleeding after extractions and surgery; it is also used to apply and hold medications within the mouth.

\section{Method and Material}

One hundred and ten patients undergoing general anaesthesia and endoscopy were studied. Before induction, Orahesive was applied over the upper incisors

"From the Department of Anesthesiology, State University Hospital, State University of New York, Upstate Medical Center, Syracuse, New York. 
and canines in the following manner: After cutting a wafer to the appropriate size, the release paper was stripped, about $u$ in. of it cut off along the edge, and the remainder re-applied to the middle so that approximately 13 in. of the Orahesive remained exposed along each edge (see Fig. 1); the shield was applied and moulded over the upper teeth (see Fig. 2). The bare Orahesive adheres firmly to the gum margin.

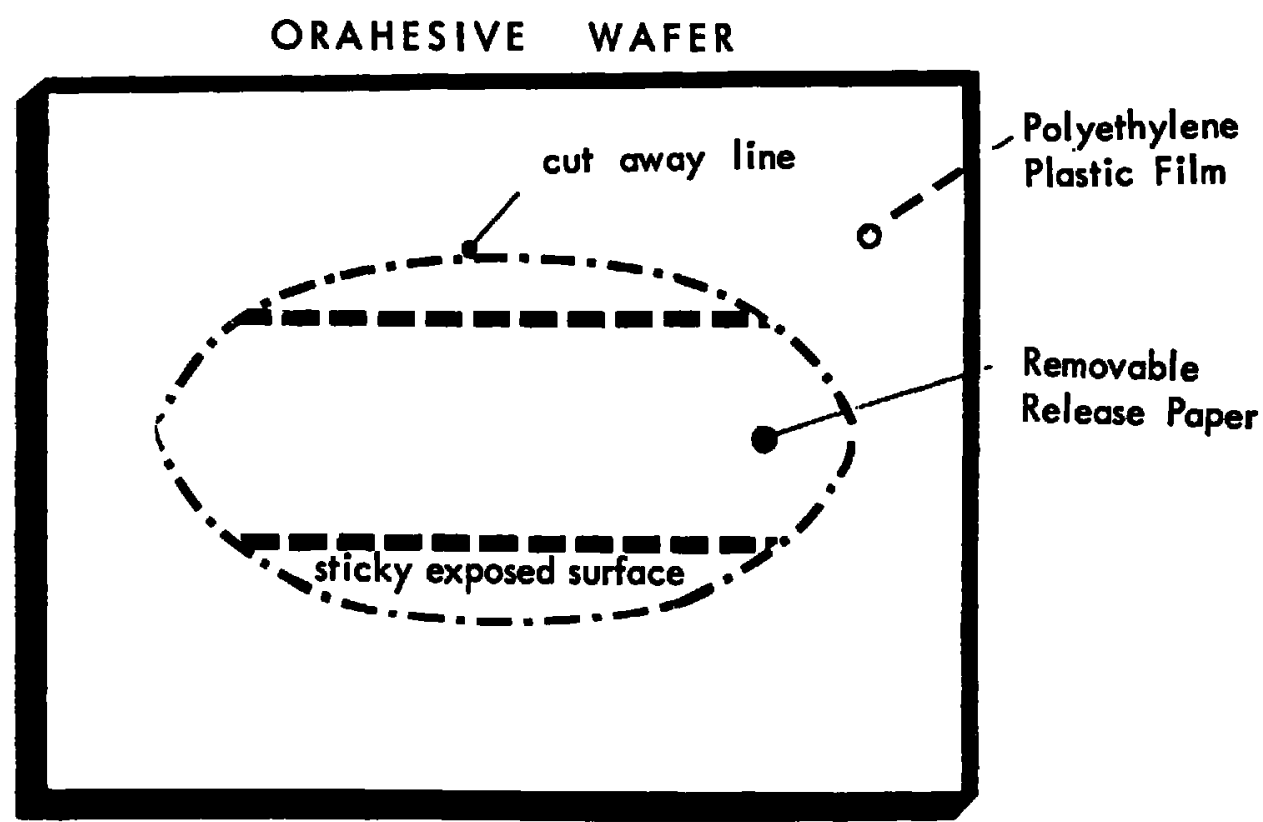

Ficure 1. Orahesive wafer (actual size $4^{\prime \prime} \times 2 \%^{\prime \prime} \times 1 / 16^{\prime \prime}$ ) showing usual manner in which it is prepared for application.
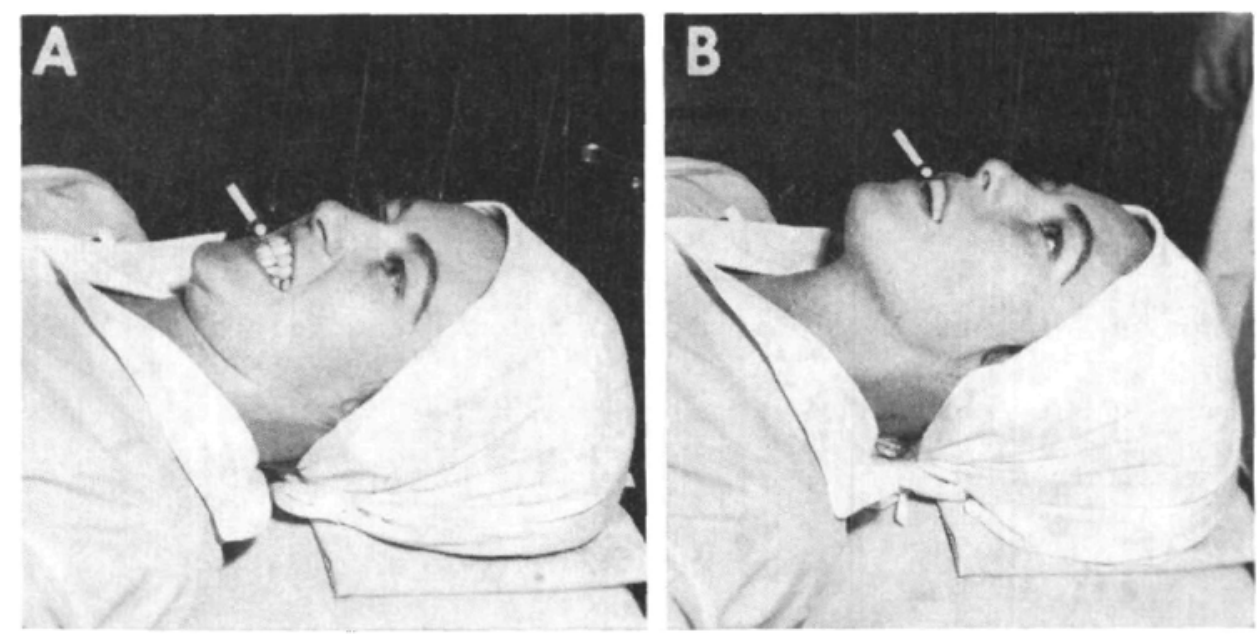

Frgune 2. (A) Patient with prominent irregular teeth exposed. This type of case would be prone to damage of upper incisors during endoscopy. (B) Orahesive wafer in place and providing the safety precaution that would be desired in such a case. 
Evaluation was made by means of a protocol containing a list of questions to be answered in each case.

\section{ResUlts}

The following information summarizes our recorded data:

1. Age of Patients

$$
\begin{array}{lcccc}
\text { Age in years } & 10-20 & 21-30 & 31-50 & \text { over } 50 \\
\text { No. of patients } & 7 & 19 & 55 & 29
\end{array}
$$

\section{State of Dentition}

In the following table the total is greater than the number of patients studied because some of them had multiple defects.

$\begin{array}{ccccc}\text { All teeth } & \text { Missing } & \text { Gaps d } & \text { Loose } & \text { Carious } \\ \text { present } & \text { caps } & \text { bridges } & \text { teeth } & \text { teeth } \\ 63 & 8 & 22 & 12 & 14\end{array}$

\section{Time Taken to Apply Orahesive}

$\begin{array}{cccc}15 \text { sec. } & 30 \text { sec. } & 1 \text { min. } & \text { More } \\ 36 & 66 & 8 & 0\end{array}$

\section{Type of Airway Established and}

Degree of Difficulty with. Endoscopy

$$
\text { Nasopharyngeal Oropharyngeal Endotracheal }
$$

$\begin{array}{lrrr}\text { Easy } & 2 & 31 & 52 \\ \text { Moderately difficult } & & 2 & 18 \\ \text { Difficult } & & & 5 \\ \text { Total } & 2 & 33 & 75\end{array}$

Airway management and intubation was classified as "easy," "moderately difficult," and "difficult" while a nasopharyngeal or an oropharyngeal airway was used. Maintenance was considered "easy" if no continuous support of the jaw was required.

\section{Irritation of Gums}

Irritation was observed in one patient in whom removal of the Orahesive was very difficult.

\section{Removal of Orahesive}

The shield was removed after recovery from anaesthesia except in four cases of oral surgery. 
7. Ease of Removal

$\begin{array}{ccc}\text { Easy, in } & \text { Small parts } & \\ \text { one piece } & \text { separately } & \text { Difficult } \\ 62 & 38 & 10^{\circ}\end{array}$

8. Duration of Time that Orahesive was in Place

$\begin{array}{cccc}1 \text { hr. } & 1-3 \mathrm{hrs} . & >3 \mathrm{hrs} . & \text { Longest }=22 \mathrm{hrs} \\ 37 & 50 & 21\end{array}$

9. Displacement of Orahesive

$\begin{array}{lcc} & \text { Whole } & \text { Parts } \\ \text { Into teeth } & 0 & 13 \\ \text { Pharynx } & 0 & 1 \\ \text { Larynx } & 0 & 0\end{array}$

\section{Damage to Teeth}

No damage occurred to the teeth in any of the cases in which the Orahesive was used. In one of the patients, a tooth was very loose prior to induction of anaesthesia and would have been dislodged by any instrumentation. Orahesive was applied over the teeth very carefully to make sure the loose tooth would not be disturbed. There was slight bleeding at the gum margin following endoscopy in this case but the tooth was not dislodged.

\section{Influence on Airway Management}

Data were recorded to determine whether or not we thought that the application of Orahesive might make any difference on the airway management.

$\begin{array}{ccc}\text { Easier } & \text { More difficult } & \text { No difference } \\ 16 & 0 & 94\end{array}$

12. Size of Orahesive Used

$\begin{array}{lccccc}\text { Size of Orahesive } & 2^{\prime \prime} \times 1^{\prime \prime} & 3^{\prime \prime} \times z^{\prime \prime} & 3^{\prime \prime} \times 1^{\prime \prime} & 3^{\prime \prime} \times 1 k^{\prime \prime} & 3^{\prime \prime} \times 2^{\prime \prime} \\ 1 / 16^{\prime \prime} \text { thickness } & 14 & 13 & 56 & 34 & 7\end{array}$

\section{SUMmary AND CONCLUSTONS}

Orahesive was applied to the teeth in 110 patients who required general anaesthesia and endoscopy. The following observations were made:

1. It was easy and quick to apply and could be cut to fit individual patients although this involved a little more time.

"In seven of these, the paper backing was removed entirely and accounted for five instances of difficult removal. As long as the release paper was kept in place where the Orahesive came in contact with the teeth, removal did not present problems. Early in the study, ointment was applied over the teeth of one patient but this prevented firm adhesion. This method was also found to be cumbersome and time-consuming and was abandoned in favour of removing a strip of the release paper. 
2. It was not uncomfortable to the patient when applied and worn, and it caused practically no irritation.

3. It was easy and quick to remove providing the release paper was replaced after removing sufficient to leave an adherent surface exposed.

4. It offered good protection for very loose teeth even in cases where laryngoscopy and intubation were judged "moderately difficult" or "difficult" and when the patient's dentition was very poor.

In order to save time in the application of Orahesive, it would be advisable to have the wafer supplied in the size $3^{\prime \prime}$ long by $1 x^{\prime \prime}$ " wide and to have a perforated margin on each side of the release paper about $3 / 16^{\prime \prime}$ wide to facilitate rapid removal of enough paper to provide an adequate adhesive surface.

\section{RÉSUMÉ}

Nous avons utilisé pour cette étude l'Orahésive 1/16" (E. R. Squibb \& Co.). C'est un composé de gélatine, de pectine, de carboxy-méthyl-cellulose de sodium et de polyisobutylène. Il a une grande affinité pour l'eau, il est solube dans l'eau et il adhère solidement aux surfaces humides. Il se présente en unités enveloppées une par une, et en trois épaisseurs. Une surface est recouverte d'une couche de polyéthylène et l'autre d'un papier qui peut être enlevé. Les unités peuvent être taillées selon la grandeur et la forme que l'on désire. En chirurgie dentaire, son principal usage est de prévenir l'hémorragie après les extractions ou autres interventions; on l'utilise aussi pour appliquer et maintenir des médicaments à l'intérieur de la cavité buccale.

On a étudié cent dix malades sous anesthésie générale pour endoscopie. Avant l'induction, on a appliqué l'Orahésive sur les incisives supérieures et sur les canines de la façon suivante: après avoir taillé un morceau de la grandeur appropriée, on enlève le papier, on le rétrécit d'un quart de pouces, on réapplique ce qui reste au centre du morceau taillé, de sorte qu'environ $1 \%$ de pouce de l'Orahésive reste exposé sur les bords (voir Fig. 1); cette pièce est alors appliquée et moulée sur les dents (voir Fig. 2). Le bord non recouvert de l'Orahésive adhère solidement aux gencives.

On a évalué les résultats au moyen d'un protocole formé d'une liste de questions auxquelles on devait répondre dans chaque cas.

On a observé ce qui suit:

1. Il était facile à appliquer rapidement; on pouvait le tailler pour convenir à chaque malade mais ceci prenait un peu plus de temps.

2. Il était bien toléré par le malade et ne causait pratiquement pas d'irritation.

3. Il était facile à enlever rapidement, pourvu que le papier fût remplacé après en avoir enlevé suffisamment pour laisser à découvert une surface adhérente.

4. Il offrait une bonne protection pour des dents branlantes, même en cas de laryngoscopie et d'intubation jugées "assez difficiles" ou "difficiles" et lorsque la dentition du malade était médiocre.

Pour sauver du temps en appliquant l'Orahésive, il serait souhaitable que le produit soit présenté en format de 3 pouces de long par 113 pouce de large; de chaque côté du papier qui s'enlève, il devrait y avoir une marge perforée d'environ 
3/16 de pouce, afin qu'on puisse facilement en enlever assez pour laisser une surface adhésive suffisante.

\section{REFERENCES}

1. Evans, F. T. \& Gray, T. C. General Anaesthesia. 2nd ed., London: Butterworths (1965).

2. Cullen, S. C. Anesthesia: A Manual for Students and Physicians, 6th ed., Chicago: Year Book Publishers (1961).

3. MAGILL, I. W. Endotracheal Anesthesia. Amer. J. Surg. 34: 450 (1936).

4. Artusio, J. F., Ji. \& MazziA, V. D. B. Practical Anesthesiology. 1st ed., St. Louis: C. V. Mosby (1962).

5. Donnetre, W. H. L. \& Huches, B. H. Care of the Teeth during Anesthesia. Anesth. \& Analg. 38: 206 (1959).

6. Giruespie, N. A. Endotracheal Anesthesia. 1st ed., Madison: Univ. of Wisconsin Press (1941). 